\title{
Pengaruh The Day Of The Week Effect, Week Four Effect dan Rogalsky Effect terhadap Return Saham Lq-45 di Bursa Efek Indonesia
}

\author{
Yunisa Rahardian Saraswati ${ }^{1}$, Cicik Setiorini ${ }^{2}$, Dhea Agatha Cornelia ${ }^{3}$ \\ ${ }^{1,2,3}$ STIE Perbanas Surabaya, Jalan Nginden Semolo 34-36 Surabaya 60118. Indonesia.
}

I N F O A R T I K E L

\section{JEL Classification}

G14

G30

Keywords :

stock return,

the day of the week effect,

week four effect,

Rogalsky effect.

\section{$A B S T R A C T$}

This study aims to examine the existence and influence of the effects of trade (the day of the week effect), the effect of the fourth week (week four effect), and the effect Rogalsky (Rogalsky effect) on stock returns. This research samples are 41 active stocks wich is listing in LQ-45 index in Indonesia Stock Exchange over a period of 2013. The statistic methods which are used to test hypotheses are one way anova, and paired t-test. The results show that the day of the week effect and week four effect exist in Indonesia Stock Exchange. But Rogalsky effect does not exist in Indonesia Stock Exchange during Januari-Desember 2013.

\section{A B S T R A K}

Penelitian ini bertujuan untuk menguji keberadaan dan pengaruh dampak perdagangan (hari efek minggu), efek dari minggu keempat (empat minggu efek), dan efek Rogalsky (efek Rogalsky) terhadap return saham. Ini sampel penelitian adalah 41 saham aktif CHITIN listing di LQ-45 Indeks di Bursa Efek Indonesia selama periode 2013. Pengujian hipotesis dilakukan dengan analysis of variance, dan t-test. Hasil penelitian menunjukkan bahwa pengaruh hari dalam satu minggu dan pengaruh minggu keempat efek terjadi di Bursa Efek Indonesia. Tapi efek Rogalsky tidak terbukti di Bursa Efek Indonesia selama Januari - Desember 2013.

\section{Pendahuluan}

Investor domestik memiliki peran penting dalam menjaga kestabilan pasar modal Indonesia. Semakin banyak jumlah investor domestik yang bertransaksi di pasar modal, maka kepemilikan saham di pasar modal turut meningkat. Saat ini, jumlah investor domestik mencapai $40 \%$ padahal sebelumnya hanya 20\%. Kenaikan ini dapat membantu pergerakan Indeks Harga Saham Gabungan (IHSG) menjadi stabil, namun kenaikan ini belum dapat dikatakan signifikan. Oleh karena itu perlu dilakukan upaya untuk meningkatkan jumlah investor domestik di pasar modal menyusul kondisi global yang tidak menentu seperti saat ini. Untuk dapat menarik investor supaya tetap aktif bertransaksi, pasar modal harus efisien. Menurut Tandelilin pasar yang efisien adalah pasar yang harga sekuritasnya sudah mencerminkan semua informasi yang ada. (Tandelilin, 2010). Dalam kenyataannya suatu pasar tidak dapat benar- benar dikatakan efisien, karena adanya anomali (ketidakteraturan) pasar yang selalu dikaitkan sebagai salah satu bentuk dari fenomena yang menganggu hipotesis pasar efisien. Terdapat 4 jenis anomali yang dikenal dalam keuangan yaitu anomali perusahaan (firm anomalies), anomali musiman (seasonal 
anomalies), anomali peristiwa atau kejadian (event anomalies) dan anomali akuntansi (accounting anomalies). (Alteza, 2006).

Anomali yang dibahas pada penelitian ini yaitu anomali kalender (bagian dari anomali musiman) yang biasa mengganggu hipotesis pasar efisien bentuk lemah. Anomali ini menyebabkan adanya kenaikan atau penurunan harga-harga saham yang berimplikasi pada keuntungan/ return investasi. Pola pergerakan return saham yang semula bersifat acak/random menjadi dapat diprediksi akibat adanya pengaruh anomali ini, sehingga para investor dapat memanfaatkan kesempatan ini untuk mendapatkan return yang tidak normal. (Jogiyanto, 2005).

Di Indonesia, penelitian fenomena the day of the week effect yang dilakukan oleh Iramani (2006) serta CahyaningDyah (2010) mendapatkan hasil yang konsisten bahwa terjadi fenomena the day of the week effect yang menyebabkan adanya perbedaan return saham pada hari perdagangan, dimana return terendah terjadi pada hari senin (monday effect).

Fenomena week four effect juga ditemukan oleh peneliti di Indonesia yaitu Iramani (2006) dan Lutfiaji (2014), yang menemukan bahwa fenomena ini menyebabkan munculnya return negatif signifikan yang terjadi pada hari senin minggu keempat dan senin minggu kelima setiap bulannya.

Diantara fenomena the day of the week effect dengan Januari effect, seorang peneliti bernama Rogalsky pada tahun 1984 menemukan hubungan menarik diantara keduanya. Rogalsky menemukan bahwa rata- rata return senin pada bulan Januari bernilai positif (january effect) sedangkan return senin di bulan lainnya adalah negatif. Hal ini menunjukkan bahwa Monday effect menghilang di bulan januari dikarenakan return pada bulan januari lebih tinggi dibandingkan return bulan lainnya. Fenomena menghilangnya return negatif pada bulan- bulan tertentu ini juga terjadi di Indonesia. Cahyaningdyah (2010) menemukan bahwa return pada bulan April lebih tinggi dibanding bulan lainnya. Berbeda dengan hasil penelitian yang dilakukan oleh Cahyaningdyah, Lutfiaji (2014) tidak menemukan adanya fenomena Rogalsky effect dikarenakan return negatif terjadi pada hari senin di keseluruhan bulan selama periode penelitian.

Penelitian ini bertujuan untuk menguji dan mengetahui keberadaan the day of the week effect, week-four effect dan Rogalsky effect pada indeks LQ-45 BEI periode 2013.

\section{Telaah Teori dan Pengembangan Hipotesis}

\section{Saham}

Saham merupakan tanda penyertaan atau kepemilikan seseorang atau badan yang berwujud selembar kertas, yang menerangkan bahwa pemilik kertas tersebut merupakan pemilik perusahaan yang menerbitkan surat berharga. (Darmadji dan Fakhruddin, 2011). Menurut Hadi (2013) ada 2 jenis saham dilihat dari hak yang melekat pada saham tersebut, yaitu saham biasa dan saham preferen.

\section{Return Saham}

Salah satu tujuan investor berinvestasi adalah untuk mendapatkan return. Return saham merupakan hasil dari selisih pembelian dengan penjualan saham. Return dibagi menjadi dua yaitu return realisasi (return yang sudah terjadi dan dihitung berdasarkan data histori) dan return ekspektasi (return yang belum terjadi tetapi diharapkan akan terjadi di masa mendatang) Jogiyanto (2010). Return terdiri dari dua komponen yaitu capital gain dan yield.

\section{Indeks Harga Saham LQ-45}

Pola pergerakan harga saham dibentuk melalui indeks harga saham. Sebuah indeks diharapkan memiliki lima fungsi di pasar modal yaitu sebagai berikut:

1. Sebagai indikator trend pasar

2. Sebagai indikator tingkat keuntungan

3. Sebagai Tolak ukur (benchmark) kinerja suatu portofolio

4. Memfasilitasi pembentukan portofolio dengan strategi pasif

5. Memfasilitasi berkembangnya produk derivatif (Fakhruddin, 2001).

Indeks LQ-45, yaitu indeks yang terdiri 
dari 45 saham pilihan yang mengacu pada likuiditas perdagangan dan kapitalisasi pasar. Saham yang terdapat dalam indeks tersebut akan selalu berubah setiap enam bulan (setiap awal bulan Februari dan Agustus). Tujuan indeks LQ45 yaitu untuk menyediakan sarana yang obyektif dan terpercaya bagi investor, manajer investasi, analisis keuangan, dan pemerhati pasar modal lainnya dalam memonitor pergerakan harga dari saham-saham yang aktif diperdagangkan. (BEI, 2010).

\section{Pasar Efisien}

Pasar yang efisien adalah pasar yang harga sekuritasnya sudah mencerminkan semua informasi yang ada (Tandelilin, 2010). Informasi yang ada bukan hanya mengacu kepada informasi yang lalu, tetapi juga informasi saat ini yang sama diterima oleh orang umum (Jogiyanto, 2010). Menurut Fama (1970) ada tiga bentuk tingkat efisiensi pasar berdasarkan pada tingkat penyerapan informasinya yaitu pasar efisien bentuk lemah, pasar efisien bentuk semi kuat dan pasar efisien bentuk semi kuat.

\section{Anomali Pasar}

The day of the week effect merupakan fenomena yang menyebabkan perbedaan hari perdagangan berpengaruh terhadap pola return saham dalam satu minggu (Alteza, 2006). Hal ini bertentangan dengan teori pasar efisien yang menyatakan bahwa return saham tidak berbeda pada setiap hari perdagangan. Biasanya return negatif signifikan terjadi pada hari Senin, sedangkan return positif terjadi pada hari-hari lainnya. Fenomena ini biasa disebut dengan Monday effect.

Menurut Sri Werastuti (2012), return pada hari senin cenderung negatif karena hasrat individual untuk melakukan transaksi pada hari senin lebih tinggi dari hari lainnya. Tingginya aktivitas transaksi perdagangan pada hari senin, menimbulkan keinginan investor untuk menjual saham daripada membelinya. Hal ini menyebabkan harga saham cenderung rendah pada hari senin. Selain itu, menurut Abraham dan Ikenberry (1994) seperti yang telah dikutip oleh Sri Werastuti bahwa investor cenderung aktif menjual saham pada hari senin terutama ketika mereka mengetahui ada berita/ informasi yang buruk di pasar. Psikologi investor dapat memainkan peran penting dalam munculnya fenomena ini.

H1:Terjadi the day of the week effect di Bursa Efek Indonesia yang menyebabkan adanya perbedaan return saham harian rata- rata dalam seminggu

\section{Efek Minggu Keempat (Week Four Effect)}

Week four effect merupakan suatu fenomena yang menyebabkan Monday Effect hanya terjadi pada minggu keempat dan kelima untuk setiap bulannya. Fenomena Week-four Effect ini berhasil diungkap pertama kali oleh Wang, Li dan Erickson (1997) sebagaimana dikutip oleh Alteza (2006:38). Yang menyatakan bahwa terjadi return negatif pada hari senin dua minggu terakhir pada bulan bersangkutan, sementara return pada hari Senin tiga minggu pertama meskipun negatif tetapi tidak signifikan. Sehingga dapat disimpulkan bahwa return hari Senin negatif yang terbesar terjadi pada dua minggu terakhir, yaitu pada minggu keempat atau kelima.

H2 : Terjadi week four effect di Bursa Efek Indonesia yang menyebabkan return negatif pada hari senin minggu ke-empat dan ke-lima setiap bulannya

\section{Efek Rogalsky (Rogalsky Effect)}

Rogalsky Effect merupakan fenomena yang ditemukan pertama kali oleh seorang peneliti bernama Rogalsky pada tahun 1984. Dalam penelitiannya, Rogalsky menemukan adanya hubungan yang menarik antara fenomena Day of the week Effect dengan January Effect, dimana ditemukan bahwa rata-rata return negatif pada hari Senin menghilang pada bulan tertentu. Di pasar modal Amerika terjadi suatu kondisi tersebut, dimana return pada bulan januari lebih tinggi dari bulan lainnya (January effect). Berbeda dengan hal tersebut, beberapa hasil penelitian di Indonesia tidak membuktikan adanya january effect. Hal ini didukung dengan hasil penelitian yang telah dilakukan oleh Cahyaningdyah (2010) bahwa return april lebih tinggi dari bulan lainnya 
(april effect). Menurut Cahyaningdyah (2010), hal ini disebabkan oleh ketentuan yang ditetapkan oleh Badan Pengawas Pasar Modal No.80/ PM/1996 berkaitan dengan sistem pelaporan keuangan dimana laporan tahunan harus disertai dengan laporan akuntan dengan pendapat yang lazim dan disampaikan kepada Bapepam 120 hari setelah tanggal tahun tutup buku yaitu pada akhir tahun. Hal ini berarti laporan keuangan maksimum disampaikan pada bulan april. Selain itu, Cahyaningdyah (2010) juga menyebutkan bahwa praktik manajemen laba yang dilakukan oleh manager menimbulkan sentimen positif pada pasar, pasar akan optimis terhadap kinerja perusahan yang melaporkan adanya kinerja yang baik sehingga dapat menaikkan harga saham. Dengan kondisi ini diduga return saham pada bulan april akan lebih tinggi dibandingkan bulan lainnya.

H3: Terjadi Rogalsky (rogalsky effect) di Bursa Efek Indonesia yang menyebabkan hilangnya return negatif pada hari senin bulan april

Kerangka pemikiran yang mendasari penelitian ini dapat digambarkan pada gambar 1 berikut ini:

\section{Metode}

\section{Klasifikasi Sampel}

Populasi dalam penelitian ini adalah perusahaan yang terdaftar di LQ-45 selama periode tahun 2013. Populasi tersebut dipilih untuk menghindari adanya saham tidur dalam menganalisis return saham. Pengambilan sampel dalam penelitian ini menggunakan metode purpose sampling dengan menetapkan kriteria sampel. Kriteria saham-saham yang akan dijadikan sampel penelitian yaitu:

1. Perusahaan yang terus menerus terdaftar di LQ-45 Bursa Efek Indonesia periode 2013. Saham yang tidak terdaftar terus menerus di LQ 45 akan dikeluarkan.

2. Perusahaan yang tidak melakukan stocksplit. Karena akan mempengaruhi harga saham.

Dari 45 saham yang tercatat di indeks LQ-45, diperoleh 41 saham yang menjadi sampel penelitian sesuai dengan kriteria pemilihan sampel.

\subsection{Data Penelitian}

Data yang digunakan dalam penelitian ini adalah data kuantitatif. Tehnik pengumpulan

\section{Gambar 1}

\section{Kerangka Pemikiran}

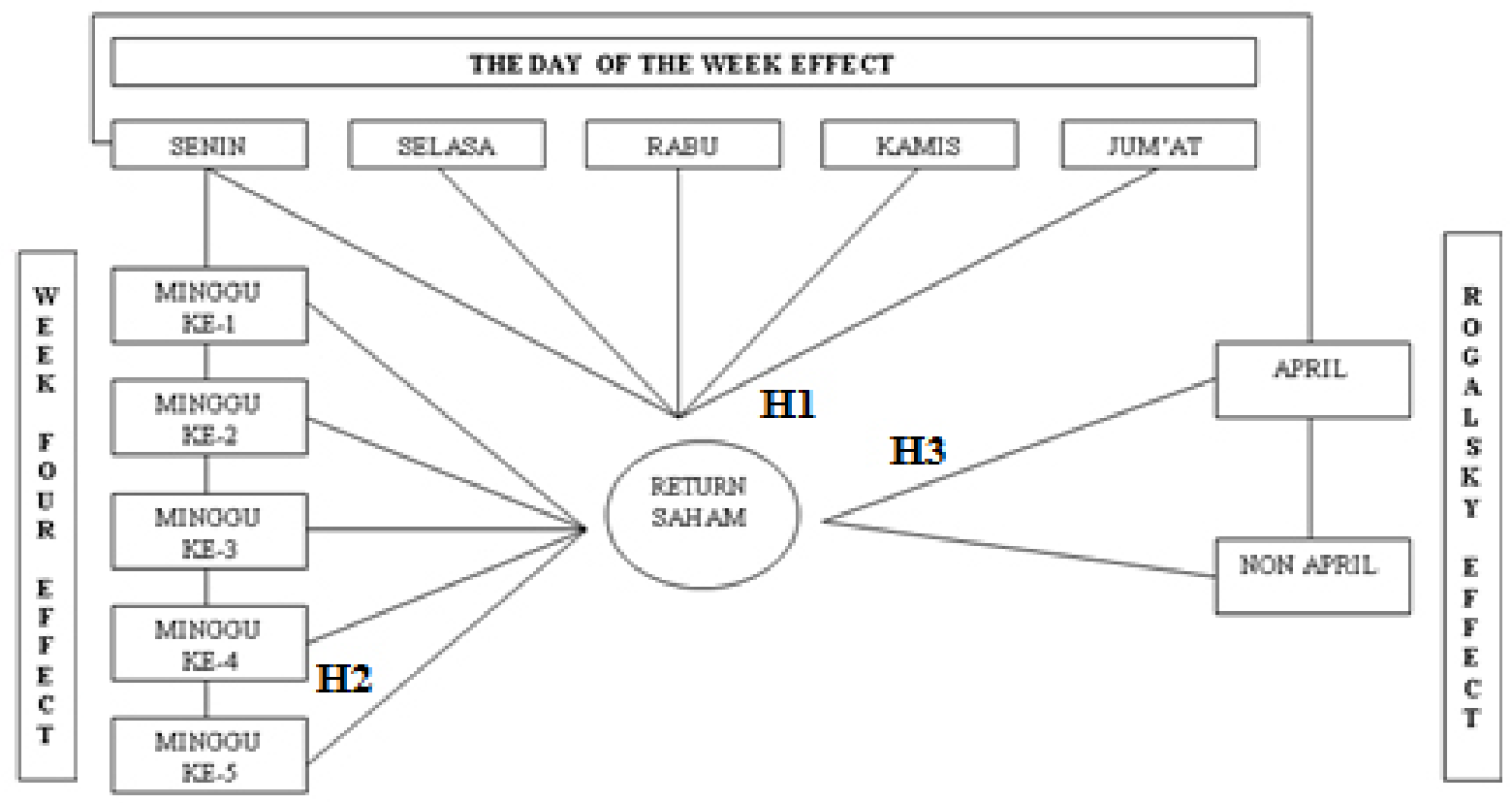


data dilakukan dengan metode dokumentasi yaitu dengan mengumpulkan semua data sekunder berupa closed price harian saham selama periode 2013 melalui situs www.idx.co.id dan www. sahamok.com

\section{Variabel Penelitian}

Variabel penelitian yang digunakan dalam penelitian ini meliputi variabel dependen yaitu return saham dan variabel independen terdiri dari efek hari perdagangan (the day of the week effect), efek minggu keempat (week four effect), dan efek Rogalsky (Rogalsky effect).

\section{Definisi Operasional Variabel Return saham}

Return saham yang digunakan dalam penelitian ini yaitu return aktual (return realisasi yang diperoleh dari suatu investasi) yang merupakan capital gain/ capital loss diperoleh dari harga saham periode saat ini (CPt) dikurangi dengan harga saham pada periode sebelumnya (CPt-1). Actual return dihitung dengan rumus sebagai berikut (Jogiyanto, 2010):

$$
\mathrm{Rt}=\underline{\mathrm{Pt}-\mathrm{Pt}-1}
$$

Dimana:

$$
\begin{aligned}
\mathrm{Rt}= & \text { return indeks saham harian pada hari } \\
& \text { ke-t } \\
\mathrm{Pt}= & \text { harga saham harian pada hari ke- } \mathrm{t} \\
\mathrm{Pt}-1= & \text { harga saham harian pada hari ke } \mathrm{t}-1
\end{aligned}
$$

\section{Efek hari perdagangan}

Hari perdagangan saham dimulai hari senin sampai jum'at. Fenomena the day of the week effect mengungkapkan bahwa return saham setiap harinya bebeda dalam satu minggu. Dimana return negatif biasanya terjadi pada hari senin atau yang biasa disebut dengan (monday effect), sedangkan return positif terjadi pada harihari lainnya (Iramani dan Mahdi, 2006).Nilai return saham untuk membuktikan fenomena hari perdagangan (the day of the week effect) diperoleh dengan cara menghitung return saham harian dari sampel perusahaan:

$$
\begin{aligned}
& \text { Rsenin }=\frac{\text { CPsenin }- \text { CPjum'at }}{\text { CPjum'at }} \\
& \text { Rselasa }=\frac{\text { CPselasa }- \text { CPsenin }}{\text { IHSIsenin }} \\
& \text { Rrabu }=\frac{\text { CPrabu }- \text { CPselasa }}{\text { CPselasa }} \\
& \text { Rkamis }=\frac{\text { CPkamis }- \text { CPrabu }}{\text { CPrabu }} \\
& \text { Rjum'at }=\frac{\text { CPjum'at }- \text { CPkamis }}{\text { CPkamis }}
\end{aligned}
$$

Return saham yang diperoleh kemudian dirata- rata sehingga diperoleh nilai return saham harian selama satu tahun. Kemudian return saham harian yang diperoleh dikelompokkan berdasarkan harinya untuk kemudian diuji dengan metode analisis data pengujian hipotesis yang digunakan yaitu ANOVA atau jika data tidak terdistribusi dengan normal digunakan pengujian Kruskal Wallis Test.

\section{Efek minggu keempat}

Week four effect merupakan fenomena yang mengungkapkan bahwa Monday Effect terjadi pada minggu keempat setiap bulannya. Sedangkan return pada hari senin pada minggu pertama sampai minggu ketiga dianggap tidak signifikan negatif atau sama dengan nol (Iramani dan Mahdi, 2006:64). Nilai return saham untuk membuktikan fenomena week four effect dilakukan dengan cara menghitung return saham hari senin setiap minggu selama tahun 2013:

$$
\text { Rsenin (minggu 1-3) }=\frac{\text { CPsenin }- \text { CPjum'at }}{\text { CPjum'at }}
$$

Rsenin $($ minggu 4$)=\underline{\text { CPsenin }- \text { CPjum'at }}$

$$
\text { CPjum'at }
$$

Return saham hari senin yang diperoleh kemudian dikelompokkan menjadi dua kelompok yaitu return saham pada minggu pertama sampai minggu ketiga dengan return saham pada minggu keempat sampai kelima. Return saham yang telah dikelompokkan tersebut diuji berdasarkan metode analisis data yang digunakan untuk menguji hipotesisnya melalui paired t-test atau jika data 
tidak terdistribusi dengan normal dilakukan pengujian Wilcoxon.

\section{Efek Rogalsky}

Rogalsky effect merupakan suatu fenomena dimana return negatif yang biasa terjadi pada hari senin (Monday effect) menghilang pada bulan tertentu (Iramani dan Mahdi, 2006:65). Nilai return saham untuk membuktikan fenomena Rogalsky effect diperoleh dengan cara menghitung return saham setiap hari senin selama tahun 2013:

$$
\text { Rsenin(April) }=\frac{\text { CPsenin }- \text { CPjum'at }}{\text { CPjum'at }}
$$

Rsenin $($ Non-April $)=\underline{\text { CPsenin }- \text { CPjum'at }}$

CPjum'at

Return saham yang diperoleh kemudian dikelompokkan menjadi dua yaitu return saham hari Senin pada bulan April dan return saham hari Senin selain bulan April. Return saham yang telah dikelompokkan kemudian diuji dengan menggunakan metode analisis. Data pengujian hipotesis yang digunakan yaitu paired t-test atau jika data tidak terdistribusi normal digunakan pengujian Wilcoxson test.

\section{Hasil Penelitian dan Pembahasan}

\section{Uji Deskriptif}

Statistik deskriptif digunakan untuk memberikan gambaran / deskripsi mengenai karakteristik variabel. Penelitian ini dilakukan pada saham perusahaan LQ-45 selama tahun 2013. Variabel yang digunakan dalam penelitian ini yaitu variabel the day of the week effect, week four effect dan Rogalsky effect. Setelah diadakan pengumpulan dan perhitungan, data yang diperlukan diolah dan dapat ditarik kesimpulan untuk menjawab hipotesis yang dikemukakan sebelumnya.

Dalam tabel 1, jumlah data saham yang digunakan untuk menghitung return harian dalam satu tahun ada 205 return. Dengan 41 data setiap harinya. Dari 205 data return diatas, hari selasa dan rabu memiliki nilai rata- rata positif sedangkan hari senin, kamis, dan jum'at memiliki nilai rata- rata negatif. Return terendah terjadi pada hari senin dengan nilai mean $-0,002655$, sedangkan return tertinggi terjadi pada hari rabu dengan nilai mean 0,002050 . Rata- rata return dari 205 saham diatas adalah $-0,000074$ yang artinya setiap 10.000 rupiah harga saham periode t-1 menghasilkan 0,74 rupiah selisih harga saham negatif dengan saham saat ini.

Tabel 1

Hasil Analisis Deskriptif variabel The Day of the Week Effect

\begin{tabular}{lcccccc}
\hline & N & Mean & Std. Deviation & Std. Error & Minimum & \multicolumn{1}{c}{ Maximum } \\
\hline Senin & 41 & -.002655 & .0032559 & .0005085 & -.0110 & .0036 \\
Selasa & 41 & .000507 & .0032997 & .0005153 & -.0086 & .0068 \\
Rabu & 41 & .002050 & .0032006 & .0004998 & -.0053 & .0091 \\
Kamis & 41 & -.000216 & .0033286 & .0005198 & -.0081 & .0070 \\
Jumat & 41 & -.000057 & .0029922 & .0004673 & -.0075 & .0083 \\
Total & 205 & -.000074 & .0035310 & .0002466 & -.0110 & .0091 \\
\hline
\end{tabular}


Tabel 2

Hasil Analisis Deskriptif variabel Week Four Effect

\begin{tabular}{lccccc}
\hline & N & Mean & $\begin{array}{c}\text { Std. } \\
\text { Deviation }\end{array}$ & Minimum & Maximum \\
\hline Return senin minggu ke 1-3 & 41 & -.001548 & .0047000 & -.0093 & .0096 \\
Return senin minggu ke 4/5 & 41 & -.005609 & .0065555 & -.0211 & .0103 \\
\hline
\end{tabular}

Dalam tabel 2, jumlah data saham yang digunakan untuk menghitung return hari senin setiap minggu dalam satu bulan ada 41 return sesuai dengan sample yang telah memenuhi kriteria. Kedua kelompok rata-rata return diatas sama-sama menghasilkan return negatif. Return pada minggu ke $4 / 5$ lebih rendah dari return pada minggu ke 1-3. Return terendah pada minggu ke 1-3 bernilai -0,0093, sedangkan return tertinggi bernilai 0,0096. Return terendah pada minggu ke $4 / 5$ bernilai $-0,0211$, sedangkan return tertinggi bernilai 0,9365 . Rata- rata return senin pada minggu ke 1-3 adalah $-0,001548$ yang artinya setiap 10.000 rupiah harga saham selama minggu 1-3 menghasilkan 15,48 rupiah selisih negatif dengan saham saat ini. Sedangkan rata- rata return senin pada minggu ke 4-5 adalah -0,005609 yang artinya setiap 10.000 rupiah harga saham selama minggu 4-5 menghasilkan 56,09 rupiah selisih negatif dengan saham saat ini.

Dalam tabel 3, jumlah data return saham yang digunakan untuk menghitung return saham setiap hari senin pada bulan april dan non april selama tahun 2013 ada 41 return, sesuai dengan kriteria sample penelitian. Dari kedua kelompok rata-rata return diatas, return senin pada bulan non april lebih rendah dari return senin pada bulan april, namun selisih perbedaan diantara keduanya tidak berbeda jauh. Return terendah pada bulan april bernilai $-0,0302$, sedangkan return tertinggi pada bulan april bernilai 0,0159. Return terendah pada bulan non april bernilai -0,0108, sedangkan return tertinggi pada bulan non april bernilai 0,0041 . Rata- rata return senin pada bulan april adalah $-0,002060$ yang artinya setiap 10.000 rupiah harga saham hari senin pada bulan april menghasilkan 20,60 rupiah selisih negatif dengan saham saat ini. Sedangkan rata- rata return senin pada bulan non april adalah $-0,002678$ yang artinya setiap 10.000 rupiah harga saham selama minggu 4-5 menghasilkan 26,78 rupiah selisih negatif dengan saham saat ini.

\section{Pengujian Normalitas Data}

Uji normalitas bertujuan untuk menguji apakah data terdistribusi secara normal atau tidak. Uji normalitas data dilakukan dengan menggunakan one sample Kolmogorov Smirnov untuk setiap variabel. Jika hasil dari pengujian one sample kolomogorv smirnov mempunyai nilai signifikansi $\alpha \geq 0.05$ maka dapat dikatakan variabel terdistribusi secara normal.

Tabel 3

Hasil Analisis Deskriptif variabel Rogalsky Effect

\begin{tabular}{lcccrr}
\hline & N & Mean & Std. Deviation & Minimum & Maximum \\
\hline Return senin pada bulan april & 41 & -.002060 & .0097971 & -.0302 & .0159 \\
Return senin pada bulan non april & 41 & -.002678 & .0033574 & -.0108 & .0041 \\
\hline
\end{tabular}


Tabel 4

One-Sample Kolmogorov-Smirnov Test

\begin{tabular}{|c|c|c|c|}
\hline & \multicolumn{2}{|c|}{ Asymp. Sig. (2-tailed) } & Keterangan \\
\hline Hipotesis 1 & 0,381 & & Terdistribusi normal \\
\hline Hipotesis 2 & 0,638 & 0,458 & Terdistribusi normal \\
\hline Hipotesis 3 & 0,583 & 0,546 & Terdistribusi normal \\
\hline
\end{tabular}

Dari tabel 4 diatas, terlihat bahwa data sampel yang akan digunakan untuk menguji seluruh hipotesis dapat dikatakan terdistribusi secara normal. Nilai signifikansi uji normalitas untuk hipotesis pertama sebesar $0,381 \geq 0,05$ artinya data terdistribusi secara normal. Untuk hipotesis kedua dan ketiga memiliki dua nilai signifikansi, yaitu masing- masing 0,638 dan 0,458 untuk hipotesis kedua, serta 0,583 dan 0,546 untuk hipotesis ketiga. Kedua nilai signifikansi yang dimiliki oleh hipotesis 2 dan 3 sama-sama memiliki nilai signifikansi $\geq 0,05$, sehingga dapat dikatakan data terdistribusi secara normal. Karena data terdistribusi secara normal, maka dapat digunakan uji parametic test untuk menguji hipotesis pertama, kedua dan ketiga. Untuk hipotesis pertama, menggunakan uji one way anova terhadap K-sampel yang independen, sedangkan untuk hipotesis kedua dan ketiga menggunakan uji Paired T-test.

\section{Hasil Pengujian dan Pembahasan The Day of the Week Effect}

Hipotesis pertama dalam penelitian ini adalah bahwa terjadi the day of the week effect di Bursa Efek Indonesia yang menyebabkan adanya perbedaan return harian saham rata- rata dalam seminggu. Hipotesis ini diuji dengan menggunakan uji one way anova. Tabel 5 menunjukkan bahwa nilai signifikansi untuk hipotesis pertama sebesar $0,000<0,05$ maka H1 diterima. Hal ini membuktikan bahwa terdapat perbedaan return saham selama 5 hari perdagangan. Return terendah terjadi pada hari senin dengan nilai $-0,002655$, sedangkan return tertinggi terjadi pada hari rabu dengan nilai 0,002050. Agar dapat memberikan gambaran yang lebih jelas, maka disajikan pola pergerakan rata- rata return harian dalam satu minggu pada gambar 2.

Dari gambar 2 terlihat adanya perbedaan rata- rata return dalam lima hari perdagangan. Hal ini disebabkan adanya perbedaan hasrat para investor untuk menjual atau membeli saham di hari- hari tertentu. Sehingga tingkat penjualan/ pembelian akan berubah setiap harinya. Adanya perubahan tingkat penjualan/ pembelian ini

Tabel 5

Ringkasan Hasil Uji Hipotesis

\begin{tabular}{llc}
\hline & \multicolumn{1}{c}{ Variabel } & Asymp. Sig. \\
\hline Hipotesis 1 & The day of the week effect & 0,000 \\
Hipotesis 2 & Week four effect & 0,007 \\
Hipotesis 3 & Rogalsky effect & 0,701 \\
\hline
\end{tabular}


menyebabkan harga saham juga akan mengalami penurunan/ kenaikan yang pada akhirnya akan mempengaruhi return saham. Return terendah terjadi pada hari senin dan return tertinggi terjadi pada hari rabu. Pada hari selasa, rata-rata return menjadi positif, hal ini bukan disebabkan karena faktor fundamental melainkan faktor teknikal. Menurut Iramani (2006), para investor pada hari selanjutnya (setelah senin) telah melakukan koreksi yang dalam serta menetapkan strategi terhadap saham yang dimilikinya. Investor menganggap harga saham pada saat itu murah sehingga banyak dari mereka yang membelinya (buy on weakness). Pembelian saham secara besar - besaran dapat memicu terjadinya technical rebound atau pergerakan saham yang berbalik arah. Hal ini dapat menyebabkan kenaikan harga saham.

Hasil penelitian ini konsisten dengan hasil penelitian yang telah dilakukan oleh Lutfiaji (2014), CahyaningDyah (2010), dan Iramani (2006).

\section{Gambar 2}

Pola pergerakan rata- rata return harian

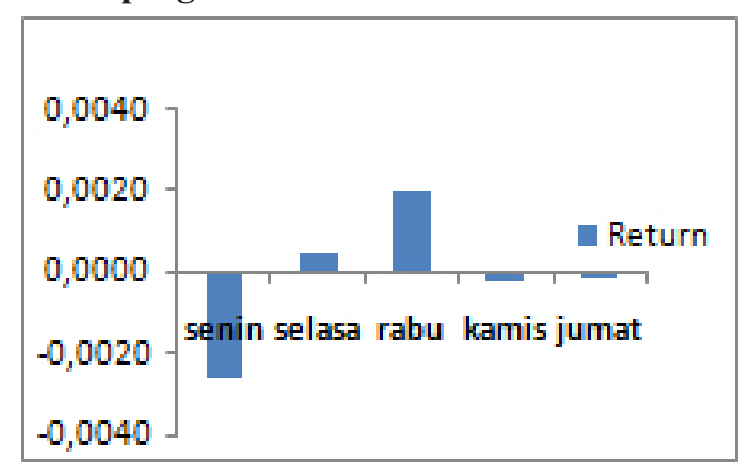

\section{Hasil Pengujian dan Pembahasan Week Four Effect}

Hipotesis kedua dalam penelitian ini adalah bahwa terjadi week four effect di Bursa Efek Indonesia yang menyebabkan munculnya return negatif pada hari senin minggu keempat dan kelima setiap bulannya. Week four effect merupakan suatu fenomena yang mengungkapkan bahwa Monday effect hanya terjadi pada minggu terakhir setiap bulannya. Sedangkan return pada minggu pertama sampai dengan minggu ketiga meskipun negatif namun dianggap tidak signifikan negatif atau sama dengan nol (Iramani,
2006).

Pengujian hipotesis ini dilakukan dengan menggunakan uji paired t-test. Tabel 5 menunjukkan nilai signifikansi untuk uji hipotesis kedua sebesar $0,007 \geq 0,05$ maka $\mathrm{H} 2$ diterima. Yang artinya ada perbedaan rata- rata return senin pada minggu pertama $(1,2$, dan 3$)$ dengan minggu terakhir (4/5). Agar dapat memberikan gambaran yang lebih jelas, maka disajikan pola pergerakan rata- rata return harian dalam satu minggu pada gambar 3 .

Dari gambar 3 terlihat bahwa kedua kelompok return tersebut sama-sama menghasilkan return negatif. Namun, return negatif pada hari senin minggu ke 4/5 lebih rendah dari return negatif pada hari senin minggu ke 1-3. Menurut Iramani (2006) adanya tuntutan untuk memenuhi segala kebutuhan utama pada awal bulan berikutnya dapat menyebabkan terjadinya tekanan jual. Tuntutan likuiditas investor individu jatuh pada setiap bulan dimana individu akan melakukan pembayaran bulanan mereka pada akhir bulan, sedangkan mereka akan membeli saham pada pergantian bulan serta menglikuidasinya pada saat mendekati akhir bulan. Sesuai dengan teori penawaran yaitu semakin banyak barang yang ditawarkan, maka akan menyebabkan penurunan harga. Penurunan harga ini menyebabkan return minggu keempat dan kelima menjadi negatif signifikan. Hal ini berimplikasi pada pembelian saham pada hari senin di minggu keempat dan minggu kelima setiap bulannya. Hasil penelitian ini konsisten dengan hasil penelitian yang telah dilakukan oleh Lutfiaji (2014), Cahyaningdyah (2010), dan Iramani (2006).

\section{Gambar 3.}

Pola pergerakan rata-rata return senin setiap minggu

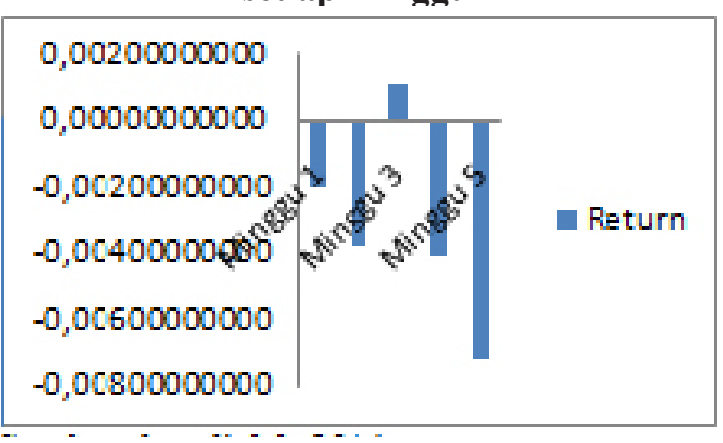




\section{Hasil Pengujian Rogalsky Effect}

Hipotesis ketiga dalam penelitian ini adalah bahwa terjadi Rogalsky effect di Bursa Efek Indonesia yang menyebabkan hilangnya return negatif signifikan pada bulan april. Menurut Cahyaningdyah (2010) hal ini disebabkan oleh ketentuan yang ditetapkan oleh Badan Pengawas Pasar Modal No.80/PM/1996 berkaitan dengan sistem pelaporan keuangan dimana laporan tahunan harus disertai dengan laporan akuntan dengan pendapat yang lazim dan disampaikan kepada Bapepam 120 hari setelah tanggal tahun tutup buku yaitu pada akhir tahun. Hal ini berarti laporan keuangan maksimum disampaikan pada bulan april. Selain itu, Cahyaningdyah (2010) juga menyebutkan bahwa praktik manajemen laba yang dilakukan oleh manager menimbulkan sentimen positif pada pasar, pasar akan optimis terhadap kinerja perusahan yang melaporkan adanya kinerja yang baik sehingga dapat menaikkan harga saham. Dengan kondisi ini diduga return saham pada bulan april akan lebih tinggi dibandingkan bulan lainnya.

Hipotesis ini diuji dengan menggunakan uji paired t-test. Tabel 5 menunjukkan bahwa nilai signifikansi untuk hipotesis ketiga sebesar $0,701 \geq 0,05$ maka $\mathrm{H} 3$ ditolak. Yang artinya tidak ada perbedaan rata- rata return senin pada bulan april dengan bulan selain april. Agar dapat memberikan gambaran yang lebih jelas, maka disajikan pola pergerakan rata- rata return harian dalam satu minggu pada gambar 4 .

Dari gambar 4 terlihat bahwa rata- rata dari kedua kelompok return tersebut tidak berbeda jauh, keduanya sama sama menghasilkan return negatif. Return senin pada bulan non april lebih rendah dari return senin pada bulan april, namun selisih perbedaan return tersebut sangat sedikit. Sehingga tidak dapat dikatakan ada beda diantara keduanya.

Saat ini investor domestik di pasar modal Indonesia meningkat tapi masih sedikit dibandingkan dengan jumlah investor asing. Seperti yang telah dikatakan oleh Lutfiaji (2014) bahwa investor asing cenderung berperilaku hatihati dalam menanamkan sahamnya. Hal itu dapat menjadi salah satu sebab peningkatan penjualan saham yang tidak diikuti dengan pembeliannya. Selain itu Pelaksana tugas Kepala Badan Kebijakan Fiskal Kementerian Keuangan seperti yang dimuat dalam harian KOMPAS (2013) menyatakan bahwa dalam triwulan pertama tahun 2013 kondisi ekonomi global masih belum sepenuhnya pulih yang berarti pertumbuhan ekonomi masih belum membaik. Hal tersebut dapat mempengaruhi kegiatan investasi. Namira Ufrida Rahmi (2011) menyatakan bahwa

"Pasar modal sangat rentan terhadap kondisi makro ekonomi. Pengaruh makroekonomi tidak seketika mempengaruhi kinerja perusahaan, tetapi secara perlahan dalam jangka panjang. Sebaliknya harga saham akan terpengaruh seketika oleh perubahan faktor makro ekonomi tersebut, karena para investor akan memperhitungkan dampaknya baik yang positif maupun yang negatif terhadap kinerja perusahaan beberapa tahun kedepan, kemudian mengambil keputusan untuk membeli, menjual atau menahan sahamnya".

Jadi di dalam kondisi seperti ini, investor akan secara cepat merespon berita/ informasi yang ada untuk kemudian mengambil keputusan terhadap saham yang dimiliknya.

Cahyaningdyah (2010) mengemukakan bahwa return pada bulan april lebih tinggi dibandingkan return pada bulan lainnya, hal ini dikarenakan adanya peraturan mengenai sistem pelaporan keuangan yang berkaitan dengan praktik manajemen laba. Dengan dilakukannya praktik manajemen laba, laporan keuangan akan terlihat baik sehingga menimbulkan sentimen positif pada pasar dan selanjutnya akan berdampak terhadap kenaikan harga saham. Namun sejak tahun 2011 Indonesia telah mengadopsi IFRS, dimana di dalam IFRS tidak membolehkan adanya praktek manajemen laba. Ari Dewi (2011), mengemukakan bahwa :

"standar akuntansi yang semakin ketat dapat menurunkan manajemen laba \& meningkatkan kualitas pelaporan keuangan. Standar IFRS yang berbasis prinsip, lebih pada penggunaan nilai wajar, dan 
pengungkapan yang lebih banyak dan rinci dapat mengurangi manajemen laba".

Hal ini berarti dengan adanya penerapan IFRS di Indonesia dapat mengurangi praktik manajemen laba. Sehingga perusahaan akan membuat laporan keuangan sesuai dengan kondisi sebenarnya, dan pasar akan menerima dan merespon sesuai dengan informasi yang ada dan selanjutnya informasi tersebut akan mempengaruhi perilaku invesor dalam kenaikan/ penurunan harga saham. .

Hasil penelitian ini konsisten dengan Lutfiaji (2014), dan Iramani (2006).

\section{Gambar 4}

\section{Pergerakan rata-rata return senin setiap} bulan selama satu tahun

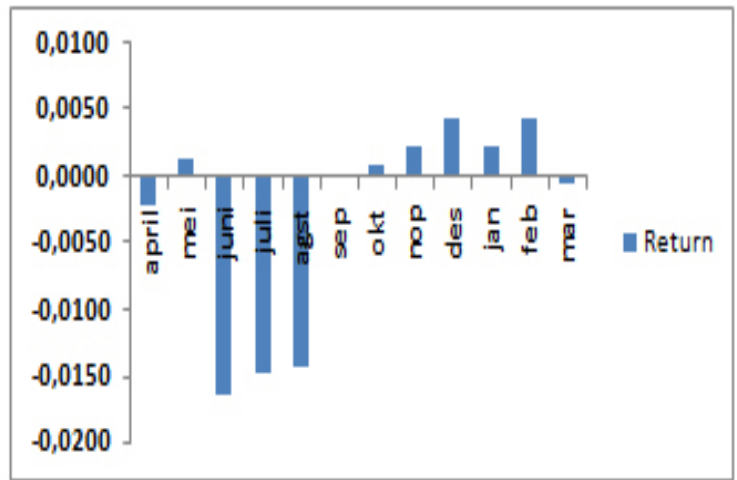

\section{Simpulan, Keterbatasan dan Implikasi Hasil Penelitian}

Penelitian ini bertujuan untuk menguji dan menganalisis the day of the week effect, week four effect dan Rogalsky effect. Sampel dalam penelitian ini adalah perusahaan yang terus menerus terdaftar di LQ-45 Bursa Efek Indonesia periode 2013 dengan jumlah sample sebanyak 41 saham. Setelah dilakukan pengujian dengan menggunakan uji normalitas kolmogorov smirnov, ditetapkan uji parametic untuk menguji hipotesis yang telah dirumuskan.

Dari hasil uji variabel the day of the week effect dengan menggunakan uji one way anova dapat disimpulkan bahwa terjadi fenomena the day of the week effect di BEI yang menyebabkan adanya perbedaan return saham harian rata- rata dalam seminggu. Hasil uji untuk variabel week four effect dengan menggunakan uji paired t-test dapat membuktikan adanya fenomena tersebut di BEI yang menyebabkan munculnya return negatif pada hari senin minggu keempat dan kelima setiap bulannya. Return negatif terendah terjadi pada minggu terakhir 4-5.

Fenomena Rogalsky Effect yang diuji dengan menggunakan uji paired t-test tidak dapat dibuktikan keberadaannya, karena tidak ada perbedaan antara return senin pada bulan april dan bulan non april.

Penelitian ini memiliki keterbatasan (1) tidak memberikan argumentasi yang mendukung terjadinya fenomena the day of the week effect, week four effect, dan Rogalsky effect (2) periode pengamatan selama 1 tahun, tidak memberikan variasi hasil yang cukup.

Berdasarkan hasil penelitian dan keterbatasan yang terdapat dalam penelitian ini, maka peneliti mengajukan saran untuk pengembangan penelitian selanjutnya, yaitu (1) diharapkan untuk memberikan argumentasi berkaitan dengan keberadaan fenomena the day of the week effect, week four effect dan Rogalsky effect (2) diharapkan pada penelitian selanjutnya periode yang digunakan lebih banyak. Supaya dapat membandingkan apakah fenomena anomali kalender terjadi setiap tahun.

\section{Daftar Pustaka}

Alteza.2006.Efek Hari Perdagangan terhadap Return Saham: Suatu Telah atas Anomali Pasar Efisien,Yogyakarta: Jurnal Ilmu Manajemen, hal.36.

Ari Dewi. 2011. "Peluang Manajemen Laba Pasca Konvergensi IFRS: Sebuah Tinjauan Teoritis \& Empiris". Jurnal Fakultas Ekonomi:JRAK, vol. 2, Pp 1-7

Cahyaningdyah, Dwi dan Witiastuti, Rini Setyo. 2010. Jurnal Dinamika Manajemen. Analisis Monday effect dan Rogalsky effect di Bursa Efek Jakarta, Vol. 1, No. 2, 2010, pp: 154168.

D.N, Sri Werastuti. 2012. Jurnal Ilmiah Akuntansi dan Humanika JINAH. Anomali Pasar pada 
Return Saham: The Day of The Week Effect, Week Four Effect, Rogalsky Effect, dan January Effect, vol. 2, No.1, 2012.

Fama, Eugene F. (May 1970), "Efficient market: A review of theory and empirical work", Journal of Finance, 25 (2): 383-417.

Fakhruddin, M. 2001. Perangkat dan Model Analisis Investasi di Pasar Modal. Jakarta: Gramedia.

Hadi, Nor. 2013. Pasar Modal, Acuan Teoritis dan Praktis Investasi di Instrumen Keuangan Pasar Modal. Yogyakarta: Graha ilmu, hal. 68

Iramani dan Mahdi, A. 2006. "Studi Tentang Pengaruh Hari Perdagangan Terhadap Return Saham pada BEJ". Jurnal Akuntansi dan Keuangan , 8 (2), 63-70.

Jogiyanto,H.M.2005. Teori Portofolio dan Analisis Investasi, Edisi 7. Yogyakarta: BPFE

Lutfiaji. 2014. Pengujian The Day of the week effect, Week Four Effect, dan Rogalsky Effect terhadap Return Saham LQ-45 di BEI, Jurnal Ilmiah Mahasiswa Fakultas Ekonomi Brawijaya Vol. 2 no. 1, 2014. pp 1-11

Namira Ufrida, Rahmi. 2011. "Analisis Pengaruh Makroekonomi”. Tesis diterbitkan, Universitas Sumatera Utara

Tandelilin, E. 2010. Portofolio dan Investasi Teori dan Aplikasi. Yogyakarta: Kanisius

T. Darmadji, dan M. Fakhruddin. 2011. Pasar Modal di Indonesia : Pendekatan Tanya Jawab. Jakarta: Salemba Empat. 